\title{
Qualitative parameters of the piapara semen (Leporinus elongatus Valenciennes, 1850)
}

\author{
Streit-Jr., DP. ${ }^{\mathrm{a} *}$, Sirol, RN. ${ }^{\mathrm{b}}$, Ribeiro, RP. ${ }^{\mathrm{c}}$, Moraes, GV. ${ }^{\mathrm{d}}$,Vargas, LDM. ${ }^{\mathrm{c}}$ and Watanabe, AL. ${ }^{\mathrm{d}}$
}

aDepartamento de Zootecnia, Faculdade de Agronomia, Universidade Federal do Rio Grande do Sul - UFRGS, Av. Bento Gonçalves, 7712, CEP 91540-000, Porto Alegre, RS, Brazil

'Gerência de Meio Ambiente, DUKE-ENERGY Brasil,

Rodovia Chavantes-Ribeirão Claro, Km 10, CEP 18970-000, Chavantes, SP, Brazil

'Departamento de Zootecnia da Universidade Estadual de Maringá - UEM, Av. Colombo, 5790, Zona 07, CEP 87020-900, Maringá, PR, Brazil

${ }^{d}$ Estação de Hidrologia e Aquacultura, Gerência de Meio Ambiente, DUKE-ENERGY Brasil, Rodovia Chavantes - Ribeirão Claro, Km 10, CEP 18970-000, Chavantes, SP, Brazil

*e-mail: danilo.streit@ufrgs.br

Received March 24, 2006 - Accepted November 23, 2006 - Distributed May 31, 2008

(With 1 figure)

\begin{abstract}
Qualitative parameters of piapara semen (Leporinus elongatus) were evaluated before and after hormonal induction with carp pituitary extract at $2.5 \mathrm{mg} \cdot \mathrm{kg}^{-1}$ of live weight. The progressive motility, the spermatic vigor and the lifetime of the spermatozoa were higher before the hormonal induction $(\mathrm{P}>0.05)$. The percentage of normal spermatozoa and spermatozoa with secondary pathologies did not differ $(\mathrm{P}>0.05)$ between treatments: before induction (44.0 and $44.4 \%$, respectively) and after-induction ( 44.3 and $46.7 \%$, respectively). However, the percentage of primary pathologies was higher $(\mathrm{P}<0.05)$ for the semen collected before induction than for the semen collected after induction; the estimates were 12.2 and $8.0 \%$, respectively. The most frequent pathologies were the taillessness with the frequencies of 27.4 and $36.3 \%$ followed by the headlessness for which the estimates were 10.1 and 3.9\%, before and after induction respectively. The semen collected before the hormonal induction presented better qualitative parameters.
\end{abstract}

Keywords: spermatic cells, spermatic morphology, fish.

\section{Parâmetros qualitativos do sêmen de piapara (Leporinus elongatus Valenciennes, 1850)}

\section{Resumo}

Os parâmetros qualitativos do sêmen de piaparas (Leporinus elongatus) foram avaliados antes e após a indução hormonal com o extrato de hipófise de carpa na dosagem $2,5 \mathrm{mg} \cdot \mathrm{kg}^{-1}$ de peso vivo. A motilidade progressiva, o vigor espermático e o tempo de vida dos espermatozóides apresentaram valores superiores $(\mathrm{P}<0,05)$ no sêmen coletado antes da indução hormonal. Já a estimativa da porcentagem de espermatozóides normais ou com patologias leves, na pré-indução (44,0 e 44,4\%, respectivamente) e na pós-indução hormonal (44,3 e 46,7\%, respectivamente) não diferiram $(\mathrm{P}>0,05)$ entre os tratamentos. Porém a estimativa de patologias graves foi maior $(\mathrm{P}<0,05)$ no sêmen de pré-indução do que no pós-induzido com 12,2 e $8 \%$, respectivamente. A patologia mais freqüente foi cabeça solta com 27,4 e 36,3\% seguida por cauda solta com 10,1 e 3,9\%, antes e após a indução hormonal respectivamente. De acordo com os resultados, o sêmen de piapara coletado na pré-indução hormonal apresentou os melhores parâmetros qualitativos.

Palavras-chave: células espermáticas, morfologia espermática, peixes.

\section{Introduction}

Piapara (Leporinus elongatus) is a freshwater fish with significant commercial value in Brazil (Duke Energy International-Geração Paranapanema S/A., 2003), and suitable for improving the fish farming economy under tropical conditions. Leporinus elongatus and Leporinus macrocephalus (Garavello e Britisk, 1988)
(Streit-Jr. et al., 2003), two species within the Anastomidae family, have an excellent background for fish growth and development in artificial ponds: $600 \mathrm{~mm}$ in length (Tataje and Zaniboni Filho, 2005).

The success of farm industries designed for raising migratory fishes depends on the semen quality for sup- 
plying the requirements of the artificial reproduction under captivity (Billard et al., 1995; Rurangwa et al., 2004). Semen quality can be affected by biotic and abiotic factors during hormonal induction and stripping procedures (Rurangwa et al., 2004). Previously, studies have evaluated the seminal characteristics of tropical fishes such as Pleuronectes ferrugineus (Silveira et al., 1990), L. macrocephalus (Streit Jr. et al., 2003), Prochilodus lineatus (Kavamoto et al., 1997; Kavamoto et al., 1999), Steindachneridion scripta (Luz et al., 2001); the seminal characteristics of L. elongatus is still lacking, except for color and quantity (Vitanea and Veja, 1995).

The quality of the semen is determined by progressive motility (Billard et al., 1995; Cosson et al., 1999; Rurangwa et al., 2004), spermatic vigor and morphology (Crosson et al., 1999), and concentration of spermatozoa. Progressive motility of the spermatozoa is the first parameter in semen quality; spermatic vigor indicates the strength of the movement; morphological defects reduce the motility and the chance of fertilization (Cosson et al., 1999); morphological analysis is not usual in fish reproduction (Kavamoto et al., 1999). Therefore, the previous understanding of parameters for quantifying the viability of the spermatozoa is significant for the success of migratory fish reproduction.

Then, the aim of this study was to evaluate the qualitative characteristics of the piapara (L. elongatus) spermatozoa collected before and after the induction with pituitary carp extract.

\section{Material and Methods}

\subsection{Local}

At first, the experiment was performed at the Hydrobiology and Aquaculture Station of the Duke Energy International-Geração Paranapanema S/A., Salto Grande County, southeastern São Paulo, Brazil; secondly, in the Laboratory of Animal Reproduction at the Universidade Estadual de Maringá, Maringá County, northwestern Paraná, Brazil.

\subsection{Fish selection}

Forty-six piapara males were random sampled from a three-year-old brood-stock for hormonal induction with a unique dose of carp pituitary extract at $2.5 \mathrm{mg} . \mathrm{kg}^{-1}$ of live weight according to Woynarovich and Horváth (1983). On average, the individual weight and size were $1,25 \pm 0.4 \mathrm{~kg}$ and $31.0 \pm 0.7 \mathrm{~cm}$, respectively. The experiment was carried out during the usual period of reproduction: the reproductive migration occurs in February at this location.
The semen samples were collected before and after the hormonal induction on the same individual performing only two treatments.

Water analysis: The physical-chemical parameters of the water in the aquarium for holding males in reproduction were measured with a Horiba ${ }^{\circledR}$ multi-parameter device (U22 model). The data are in the Table 1.

\subsection{Semen collection}

In the laboratory, fish identification by numbers was tagged with a rubber attached to the dorsal fin by a nylon string (Harvey and Carolsfeld, 1993). The draw of semen after hormonal induction was established at 220 thermal accumulated units (TAU), a threshold value for piapara reproduction. The semen extrusion was performed in a $1.0 \mathrm{~mL}$ graduated syringe. On average, $0.3 \mathrm{~mL}$ of semen were collected from the genital pore previously cleaned up with a soft paper towel to prevent contamination by water, urine and excrements (Billard et al., 1995). At some suspicion of contamination, the semen was discarded and the fish was replaced; thereafter, the fishes returned to the original tanks. Spermatozoa vigor and motility were assayed in two semen smears prepared immediately after the collection.

\subsection{Semen analysis}

Analysis of progressive motility, spermatic vigor, lifetime and morphology of the spermatozoa were performed with an optical microscope at magnification of $40 x$. The analytical procedures taken on for semen analysis are summarized as follows:

a) Progressive motility and spermatic vigor - One drop $(0.02 \mathrm{~mL})$ was diluted into eight drops $(0.16 \mathrm{~mL})$ of distilled water on a glass slide. From such dilution one drop was spread on a microscope glass slide coated with a cover slip, taken to a pre-adjusted microscope at magnification of 40x. The spermatozoa were classified for progressive motility, on a scale from 0 to $100 \%$, and for spermatozoa vigor on a scale from 0 to $5 \%$, as recommended by Sorensen Jr. (1979).

b)Lifetime - The period in which the tail is in permanent movement was investigated following the semen dilution; the time was considered and registered until the last spermatozoon stopped moving.

c) Spermatozoa morphology - A semen sample was diluted into a buffered saline-formaldehyde solution (1:2000), and was smeared on a glass slide. The smears were stained with "Bengal Rose"

Table 1. Physical-chemical parameters of the water for storing the piapara males (L. elongatus).

\begin{tabular}{ccccc}
\hline \multicolumn{5}{c}{ Physical-chemical parameters } \\
\hline $\begin{array}{c}\text { Temperature } \\
\left({ }^{\circ} \mathbf{C}\right)\end{array}$ & $\begin{array}{c}\text { Potential Hydrogen } \\
\text { ion }(\mathbf{p H})\end{array}$ & $\begin{array}{c}\text { Dissolved Oxygen } \\
\left(\mathbf{m g . L ^ { - 1 } )}\right.\end{array}$ & $\begin{array}{c}\text { Electric Conductivity } \\
\left(\mathbf{m S . c m}^{-1}\right)\end{array}$ & Turbidity \\
\hline $26.9 \pm 0.5$ & $8.33 \pm 0.15$ & $5.48 \pm 0.3$ & 0.044 & 13.00 \\
\hline
\end{tabular}


(Conn, 1918), and was dried for counting (200 to 230) and classification according to the presence of primary or secondary pathologies. The primary pathologies investigated were bent, coiled, crooked tail, crooked head, small head, giant head and twin tail. The secondary pathologies investigated were shoe-hook, headless, tailless and immature spermatozoa.

\subsection{Statistical analysis}

The piapara semen, taken before and after hormonal induction (two treatments) was analyzed in a completely randomized design in which each sample of semen collected was an experimental unit. The statistical model $\mathrm{Y}_{\mathrm{ij}}=\mu+\mathrm{T}_{\mathrm{i}}+\mathrm{e}_{\mathrm{ij}}$ was run in PROC GENMOD (SAS, 1992) for generalized linear models in which $\mathrm{Y}_{\mathrm{ij}}=$ observation from the animal (j) in the treatment (i); $\mu=$ general constant; $\mathrm{T}_{\mathrm{i}}=$ effect of treatment (i); $\mathrm{e}_{\mathrm{ij}}=$ random error with Poisson distribution, and the logarithm link function, associated with the animal (j) in the treatment (i).

\section{Results}

Progressive motility $(53.72 \%)$ and spermatic vigor ( 2.93 points) were higher $(\mathrm{P}<0.05)$ before hormonal induction; after hormonal induction, the spermatozoa presented $36.72 \%$ for progressive motility and 2.37 points in the vigor scale (Table 2).

The spermatozoa lifespan from the samples taken after hormonal induction was shorter $(\mathrm{P}<0.05)$ than those ones taken before the hormonal induction (Table 2).

Estimates of normal spermatozoa did not vary for samples taken before and after hormonal induction (Table 2). Secondary pathologies did not differ before or after hormonal induction (44.4 and $46.7 \%$, respectively) (Table 2); however, the primary pathologies (12.2\%) were enhanced by more than $50 \%$ in comparison with the $8 \%$ from the semen collected after hormonal induction (Table 2).

Regarding the incidence of pathologies, the semen taken before hormonal induction presented higher or equal estimates for primary or secondary pathologies, except for taillessness (Figure 1).

\section{Discussion}

The progressive motility after the hormonal induction was reduced by $31.65 \%$ in comparison with the treatment in which the semen was taken before hormonal induction (36.72 in comparison with $53.72 \%$ ). These estimates were lower than the progressive motility of $81.07 \%$ observed in L. obtusidens Valenciennes, 1836, also induced to spermiation by the pituitary extract of carp (Murgas et al., 1999).

Spermatic vigor was $20 \%$ smaller for semen collected after the hormonal induction than before the induction. Differently, Vermeirssen et al. (2003) observed significant increases from non-induced animals in comparison with spermatozoa of the Atlantic halibut (Hippoglossus hippoglossus Linnaeus, 1758) after hormonal induction with Gonadotropic Releasing Factor Hormone Analogous (GnRHa).

Progressive motility and spermatic vigor were quite different from the expected, because the hormone acting on piapara fishes induced significant reduction in the estimates of both qualitative traits. Previously, progressive motility in the spermatozoa of Pleuronectes ferrugineus was influenced by changes in the metabolism of progesterone that increase the effects of the gonadal hormone (Clearwater and Crim, 1998); damages from osmolarity

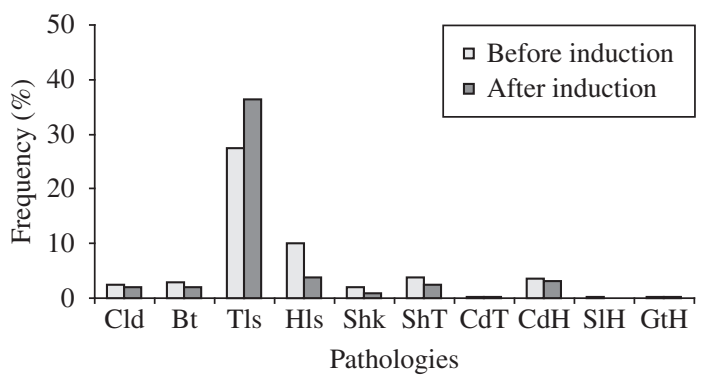

Figure 1. Pathologies of spermatozoa observed in L. elongatus before and after hormonal induction according to the frequencies of coiled (Cld), bent (Bt), tailless (Tls), headless (Hls), shoehook (Shk), short tail (ShT), crooked tail $(\mathrm{CdT})$, crooked head $(\mathrm{CdH})$, small head $(\mathrm{SlH})$ and giant head $(\mathrm{GtH})$ defects.

Table 2. Estimates for describing the quality of spermatozoa from piapara semen collected before and after hormonal induction.

\begin{tabular}{lcc}
\hline \multicolumn{1}{c}{ Parameters } & \multicolumn{2}{c}{ Hormone induction } \\
\cline { 2 - 3 } & Before & After \\
\hline Progressive motility (\%) & $53.72 \pm 3.48 \mathrm{a}$ & $36.72 \pm 3.61 \mathrm{~b}$ \\
Spermatic vigor (0 to 5 points) & $2.93 \pm 0.12 \mathrm{a}$ & $2.37 \pm 0.12 \mathrm{~b}$ \\
Spermatozoa lifespan (seconds) & $50.24 \pm 1.26 \mathrm{a}$ & $39.77 \pm 1.33 \mathrm{~b}$ \\
Normal spermatozoa (\%) & $44.00 \pm 2.30$ & $44.30 \pm 1.80$ \\
Primary pathologies (\%) & $12.20 \pm 0.80 \mathrm{a}$ & $8.00 \pm 1.1 \mathrm{~b}$ \\
Secondary pathologies (\%) & $44.40 \pm 2.87$ & $46.70 \pm 3.12$ \\
\hline
\end{tabular}

different letter on the same line, indicates significant difference between estimates $(\mathrm{P}<0.05$, by the $\mathrm{F}$ test). 
changes and ATP decreases are also reducing factors acting on spermatozoa motility (Gwo, 1995). Additionally, Cosson et al. (1999) reported that the progressive motility can be influenced by $\mathrm{pH}$, cationic concentration, cationic interaction, temperature and environmental osmolarity.

The lifespan of the spermatozoa was meager after hormonal induction; the estimates taken before and after hormonal induction, were 50.24 and 39.77 seconds respectively; pretty lower than 216.59 seconds reported by Murgas et al. (1999) for L. obtusidens; in agreement with the Cosson's statement in which the diluted semen from the majority of freshwater fish species presents spermatozoa with maximum movement, but dying in less than one minute (Cosson et al., 1999).

Primary structural defects in the piapara spermatozoa were verified in greater amounts before hormonal induction. It seems that the carp pituitary extract promotes reduction of these primary structural defects. The estimates of primary pathologies in spermatozoa of piavuçú (L. macrocephalus) were higher than $12.50 \%$ (Streit Jr. et al., 2003). Therefore, in addition to the factors which affect the gamete quality (Bromage, 1995), the type of hormone for inducing milt must be emphasized.

Estimates of both primary and secondary pathologies in the semen of piapara before and after hormonal induction (56.60 and $54.70 \%$, respectively) must be mentioned. Cosson et al. (1999) pointed out the limitation of motility as the factor for reducing the ovule fertilization. In fish, there is no reference about a threshold value for semen pathologies which do not jeopardize fertilization, though they are well established for mammals. The Colégio Brasileiro de Reprodução Animal (1998) recommended that primary or secondary defects should be lower than $30 \%$ for bovine and equine, and lower than $20 \%$ for swine and ovine. However, the percentage of secondary or primary pathologies, amongst the species of the Anastomidae family, has been divergent. The sum of primary and secondary spermatozoa structural defects in L. macrocephalus was approximately $50 \%$ for extracts of carp and chicken pituitary (Streit Jr. et al., 2003) unlike $7.06 \%$ found for L. obtusidens (Murgas et al., 1999). In mammals, primary pathologies are related with spermatogenesis (Herman et al., 1994).

Taillessness was the most frequent defect either before or after hormonal induction, but the highest incidence was found after hormonal induction. However, secondary or minor pathologies such as headlessness and taillessness in mammals can be associated with temperature, illnesses, animal diet, problems in the seminal duct, semen extrusion and smear preparation (Herman et al., 1994) In fish there are no reports about illnesses or its origin, except for extreme-structural changes in the spermatozoa after cryopreservation.

Hormonal effects of carp pituitary extract on the piapara semen did not stimulate primary pathologies. This fact should be related with the spermatogenesis (Herman et al., 1994; Hafez and Hafez 2000). However, these authors reported an estimate lower than $10.0 \%$ for primary and secondary pathologies; an estimate which was not significant in comparison to the present results.

The quality of the piapara semen collected before hormonal induction was better for the traits investigated by this experiment. Moreover, hormonal induction is usually necessary for increasing in the semen volume in Leporinus.

Acknowledgements - Research supported by Duke EnergyGeração Paranapanema S/A.

\section{References}

BARTH, AD. and OKO, RJ., 1989. Abnormal morphology of bovine spermatozoa. Ames: Iowa State University Press, 285 p.

BILLARD, R., COSSON, J., CRIM, LW. and SUQUET, M., 1995. Sperm physiology and quality. In BROMAGE, N. and ROBERTS, RJ. (orgs.). Broodstock management and egg larval quality. Oxford: Blackwell Science, 424 p.

BROMAGE, N., 1995. Broodstock management and seed quality. In BROMAGE, N. and ROBERTS, RJ. (orgs.). Broodstock management and egg larval quality. Oxford: Blackwell Science, 424 p.

CASTAGNOLLI, N., 1992. Espécies nativas próprias para a piscicultura. In CASTAGNOLLI, N. (org.). Piscicultura de água doce. Jaboticabal: FUNEP, $189 \mathrm{p}$.

CLEARWATER, SJ. and CRIM, LW., 1998. Gonadotropin releasing hormone-analogue treatment increases sperm motility, seminal plasma $\mathrm{pH}$ and sperm production in yellowtail flounder Pleuronectes ferrugineus. Fish Physiol. Biochem., vol. 19, no. 3, p. 249-257.

CBRA - COLÉGIO BRASILEIRO DE REPRODUÇÃO ANIMAL, 1998. Manual para Exame Andrológico e Avaliação do sêmen animal. Belo Horizonte: CBRA, 49 p.

COSSON, J., DREANNO, C., BILLARD, R., SUQUET, M. and CIBERT, C., 1999. Regulation of axonemal wave parameters of fish spermatozoa by ionic factors. In GAGNON, C. (org.). The male gamete: From basic science to clinical applications. Paris: Cache River Pres, 500 p.

CONN, HJ., 1918. The microscopic study of bacteria and fungi in soil. N. Y. Agric. Exp. Stn. Tech. Bull., vol. 64, no. 1, p. 3-20.

DUKEENERGY INTERNATIONAL, Geração Paranapanema, 2003. Peixes do rio Paranapanema. São Paulo: Horizontes Geográfico, 112 p.

GWO, JC., 1995. Ultrastructural study of osmolality effects on spermatozoa of three marine teleost. Tissue \& Cell, vol. 27 , no. 5 , p. 491-497.

HAFEZ, ESE. and HAFEZ, B., 2000. Reproduction in farm animals. Philadelphia: Lippicott Williams e Wickins, 509 p.

HARVEY, B. and CAROLSFELD, J., 1993. Induced breeding in tropical fish culture. Ottawa: IDRC, $144 \mathrm{p}$.

HERMAN, HA., MITCHELL, JR. and DOAK, GA., 1994. The artificial insemination and embryo transfer of diary and beef cattle. Illinois: Interstate Publishers, 392 p.

HONEYFIELD, DC. and KRISE, WF., 2000. Measurement of milt quality and factors affecting viability. In: TIERSCH, TR. 
and MAZIK, PM. (orgs.). Cryopreservation in aquatic species. Baton Rouge: World Aquaculture Society, 439 p.

KAVAMOTO, ET., PINTO, CSRM., TALMELLI, EFA. and CAMPOS, BES., 1997. Produção espermática do curimbatá Prochilodus scrofa Steindachner, 1881. Bol. Inst. Pesca, vol. 24, no. único, p. 71-78.

KAVAMOTO, ET., BARNABE, VH., CAMPOS, BES. and ANDRADE, EFT., 1999. Anormalidades morfológicas nos espermatozóides do curimbatá, Prochilodus lineatus (Steindachner, 1881) (Osteichthyes, Characiformes, Prochilodontidae). Bol. Inst. Pesca, vol. 25, no. único, p. 61-66.

LAHNSTEINER, F., PATZNER, RA. and WEISMANN, T., 1993. Energy resources of spermatozoa of the raibow trout (Oncorhynchus mykiss) (Pisces, Teleostei). Reprod. Nutr. Dev., vol. 33, no. 4, p. 349-360.

LUZ, RK., FERREIRA, AA., REYNALTE-TATAJE, DA. and ZANIBONI-FILHO, E., 2001. Avaliação qualitativa e quantitativa do sêmen de suruvi, Steindachneridion scripta (Pimelodidae). Bol. Inst. Pesca, vol. 27, no. 1, p. 39-42.

MURGAS, LDS., SILVA, MOB., MELLO, CBM., KABEYA, DM. and SANTANA, GM., 1999. Avaliação quantitativa e qualitativa do sêmen de piaparas (Leporinus obtusidens). Rev. Bras. Reprod. Anim., vol. 23, no. 3, p. 246-248.

SAS Institute Inc., 1992. SAS technical report. Release 6.07. NC, Cary, 229 p.
SILVEIRA, WF., KAVAMOTO, ET., CESTAROLLI, MA., GODINHO, HM., RAMOS, SM. and SILVEIRA, AN., 1990. Avaliação espermática, preservação criogênica e fertilidade do sêmen do pacu, Piaractus mesopotamicus (Holmberg), proveniente de reprodução induzida. Bol. Inst. Pesca, vol. 17, no. único, p. 1-13.

SORENSEN-Jr., AM., 1979. A laboratory for animal reproduction. Massachusetts: American Press, 153 p.

STREIT-JR., DP., MORAES, GV., RIBEIRO, RP., CAÇADOR, WC., SAKAGUTI, ES., POVH, JA. and SOUZA, ED., 2003. Estudo comparativo da indução hormonal da espermiação em piavuçú (Leporinus macrocephalus) com extrato de hipófise de frango, coelho e carpa. Acta Scientiarum, vol. 25, no. 2, p. 261-266.

VALE-FILHO, VR., 1980. Patologia do sêmen. Belo Horizonte: Universidade Federal de Minas Gerais-Escola de Veterinária, $54 \mathrm{p}$.

VERMEIRSSEN, ELM., QUERO, CM., SHIELDS, RJ., NORBERG, B., KIME, DE. and SCOTT, AP., 2003. Fertility and motility of sperm from Atlantic halibut (Hippoglossus hippoglossus) in relation to dose and timing of gonadotrophinreleasing hormone agonist implant. Aquaculture, vol. 230, no. $1-4$, p. 547-567.

WOYNAROVICH, E. and HORVÁTH, L., 1983. A propagação artificial de peixes de águas tropicais: manual de extensão. Brasília: Escopo, 220 p. 